\title{
Role of Transnational Corporations in the Evolution of a High- tech Industry The Case of India's Software Industry
}

Patibandla, Murali; Petersen, Bent

Document Version

Final published version

Publication date:

2001

License

CC BY-NC-ND

Citation for published version (APA):

Patibandla, M., \& Petersen, B. (2001). Role of Transnational Corporations in the Evolution of a High-tech Industry: The Case of India's Software Industry. Department of International Economics and Management, Copenhagen Business School. Working Paper / Department of International Economics and Management, Copenhagen Business School No. 5-2001

Link to publication in CBS Research Portal

\section{General rights}

Copyright and moral rights for the publications made accessible in the public portal are retained by the authors and/or other copyright owners and it is a condition of accessing publications that users recognise and abide by the legal requirements associated with these rights.

\section{Take down policy}

If you believe that this document breaches copyright please contact us (research.lib@cbs.dk) providing details, and we will remove access to the work immediately and investigate your claim. 


\section{Murali Patibandla \\ and \\ Bent Petersen}

Role of Transnational Corporations in the

Evolution of a high-tech Industry:

The Case of India's Software Industry

WP $5-2001$ 


\title{
Role of Transnational Corporations in the Evolution of a high-tech Industry: The Case of India's Software Industry ${ }^{1}$ ] \\ Murali Patibandla ${ }^{2}$ \\ and \\ Bent Petersen \\ Department of International Economics and Management \\ Copenhagen Business School \\ Denmark
}

\begin{abstract}
:
India's software industry presents the case of an internationally competitive high-tech industry from a developing economy. This paper takes the evolution of the industry in terms of human capital accumulation. The initial stock of human capital in India led to entry of TNCs, which triggers a cumulative process of further human capital accumulation through the market structure dynamics and spillovers. This paper develops a simple theory and tests the propositions empirically. The empirical analysis is based on both qualitative information collected through field interviews and econometric analysis of firm level panel data. There is significant evidence to the positive contribution of TNCs for the competitive evolution of the industry.
\end{abstract}

\footnotetext{
${ }^{1}$ We are grateful DANIDA (The Danish Development Agency) for funding the research for this paper and to Akila Narayanan and B.V.Phani for research assistance and to the managers of the companies who provided us with the data and information about their units during our fieldwork in India.

${ }^{2}$ The corresponding author: E-mail: mp.int@cbs.dk
} 


\section{Introduction}

India's software industry presents the case of internationally competitive high-tech industry from a developing economy. India's exports of software services, which accounted for U.S \$ 128 million in 199091 increased to $\$ 6.2$ billion in 2000-01 (see Table 1). The industry's exports of services, which started at the low-end of data feeding, and onsite projects in the early and mid-80s have been moving up on the quality ladder of offshore development, niche products, and software consultancy services by the beginning of the new millenium (Nasscom Report, 2000, Table 2). All most all the major U.S and European IT firms have set up software development and R\&D centers in India, especially in Bangalore.

The competitiveness of the industry is generally attributed to low cost of scientific and engineering manpower with English language skills (Heeks, 1996; Hanna, 1994). The industry has been able to achieve export competitiveness without a domestic market base and inefficient input industries and infrastructure of telecommunications (Ghemawat and Patibandla, 1999, Patibandla, Kapur and Petersen, 2000). The main critical input has been the human capital. The competitive dynamics of high technology industries, which are subject to rapid technological change in the international markets, are caused by more than just endowment of large pool of low cost skilled manpower. The interaction between the policy factors, openness to international trade and foreign direct investment, and local technological and financial institutions and firm level dynamics determine the technological evolution of high tech industries. This paper focuses on the issue of the role of TNCs in the technological evolution of India's software industry.

There is a large body of literature in development economics, which shows how openness of an economy is a source of growth for developing economies through technological, and informational externalities (spillovers) (Romer, 1986, 1990; Grossman and Helpman, 1991). The benefits of externalities associated with openness are supposedly important for developing economies because major part of technological change and generation of new ideas takes place in developed economies with huge investments in research

\footnotetext{
${ }^{3}$ In 1999-2000, 185 out of 500 Fortune companies outsoursed their software requirements to India
} (Naascom Report, 2001). 
and development. Openness facilitates technological diffusion owing to public goods nature of new ideas and technologies. TNCs are observed to be important transmitters of new technologies because their operations cause demonstration effect to local firms to imitate the best practices, technological and informational spillovers to local firms and workers (Branstetter, 2000 Aitken and Harrison, 1999, Grossman and Helpman, 1991, Branstetter, 2000; Kokko, 1994).

However this process and the magnitude of the benefits depends on several conditions such as the endowment of local skills, technology institutions and market institutional conditions, local market size and technology level and activities of local firms and the policy factors. Furthermore, the extent of the net benefits depends on the nature of TNCs' operations, which in turn is governed by the conditions listed earlier. The nature of operations refers to local and export market focus and centralized Vs decentralized operations in terms of backward and forward linkages with the local economy (Dunning 1993; Archibugi and Iammarino, 1999). To illustrate this, a TNCs that operates as a highly integrated unit in a developing economy with the main motive of taking advantage of low cost skilled labor for exports will cause lower benefits than a TNC that builds backward and forward linkages in the host economy. This issue is highly relevant to the case of India's software industry, as it has been mostly an export-oriented industry with relatively low local market focus.

The factors that determine FDI inflows into a high tech industry also govern the nature of the operations of TNCs. To illustrate an example, if the host economy possess low cost high skilled labor but lacks market institutions that protect intellectual property rights and institutions for contract formulations and enforcement makes TNCs to operate as closed and integrated units with purpose of utilizing low cost skilled labor mainly for exports. It will discourage TNCs from getting into joint ventures with input suppliers or outsourcing within the host economy for fear of appropriation of their technology by local firms. This in turn reduces the magnitude of potential spillovers.

The issue of spillovers is a part of economic growth process, which imply inter-temporal change in the economic factors. For example, spillovers increase skills of workers and under competitive input and 
product market conditions, it leads increase in wages and incomes. This in turn emanates incentive for local manpower to acquire industry specific skills, which increases the pool of local skilled manpower. Furthermore, spillovers cause growth of the local industry, which in turn may change local market institutions for better. This in turn may provide further incentive for FDI inflow and change in the nature of operations of TNCs in the host economy, which can increase the magnitude of the spillovers over time. This paper focuses on the issue of the effect of TNC operations in the Indian industry on human capital accumulation and consequent evolution of the industry. The theoretical framework is drawn from the recent developments in the endogenous growth theory pioneered by Romer (1986) and Lucas (1988). The initial human capital, industrial and institutional endowments of the country determine the entry and nature of operations of TNCs. This, in turn, determines the dynamic process of further human capital accumulation and growth. In order to understand this dynamic process, we analyze the determinants of FDI into India's software industry and the contribution of TNCs to the evolution of the industry.

In Section 2, we present the theoretical model. In Section 3, we trace out the determinants of FDI in the Industry. The empirical analysis is made in Section 4, which illustrates the net benefits of FDI to the local economy. Section 5 provides the concluding remarks and policy implications. Appendix 1 provides the detailed background of the industry. The observations and conclusions are based on both secondary and primary data. The primary data and information was collected on the basis of extensive field interviews of TNCs and local firms located in Bangalore, Hyderabad and Delhi. The interviews were conducted on the basis of an extensive questionnaire. The field study covered 30 firms out of which 14 are TNCs and the rest are local firms.

\section{The Theory:}

Our theory draws from the endogenous growth theory of Romer (1986) and Lucas (1988). It is set in the context of a human capital intensive high tech industry in a developing economy. As mentioned before, our focus is on the contribution of multinational investment to human capital accumulation and technological change. 
We take the evolution of the industry in terms of increase in workers productivity and increase in the industry size. Increase in the industry size is taken as increase in employment and total revenues. Increase in total revenues is caused by increase in workers productivity over time and the scale effect of increase in number of skilled workers. Workers productivity is a function of capital accumulation and technological change. Following Lucas (1988) we separate capital into physical capital and human capital. In the present case we focus on human capital accumulation although physical capital plays an essential but subsidiary role. This is quite germane, as the software industry is primarily a human capital intensive industry. Human capital takes place in schools, in research organizations and in the course of producing goods and engaging in trade (Lucas 1993). In Lucas model: $\mathrm{Yj}=\mathrm{A}(\mathrm{H}) \mathrm{F}(\mathrm{Kj}, \mathrm{Hj}), \mathrm{Y}$ is output, $\mathrm{A}$ represents technology as the scale variable, $\mathrm{Kj}$ stock of physical capital, $\mathrm{Hj}$ is stock of human capital. Technological change is a function of human capital. From this one can see a two-way causation between workers productivity and technological change. Level of human capital stock in terms of both numbers and level of skills determine the productivity. Human capital invested in research and development leads to new ideas, blueprints, which in turn further increase productivity. New ideas and technologies and learning by doing by economies associated with new technologies further enhance human capital accumulation (skill levels). Romer (1990) shows that an economy with a larger stock of human capital will experience faster economic growth.

The initial stock of human capital and a part of technological change are treated as exogenous i.e., technology brought-in by TNCs into the Indian industry developed in their home country operations. The technology brought in by TNCs is a function of initial stock of human capital, which could be treated as generated by the government investment in higher education and research and development. Entry of TNCs causes the dynamic process of endogenous technological change. We concentrate on the issue of technological spillovers in augmenting human capital formation as part of the endogenous growth process.

As it is well known in the literature, most of the technological change in terms of new products, ideas and blueprints are generated in the developed economies. A major part of the economic growth in developing

\footnotetext{
${ }^{4}$ We do not deal with the issue of labor replacing technological change, we assume technological change can be neutral or skill worker augmenting..
} 
economies is a matter of imitating new technologies. Open policies towards international trade and multinational investment is a major source of technological and knowledge externalities (spillovers) to developing economies. We examine the issue of externalities associated with TNCs operations in India.

Inter-temporal increase in human capital is treated as the growth process. We take the base year To. The investment and technology brought in by TNCs is a function of exogenously given stock of human capital at time period To. The stock of human capital at time To has been generated by the government investment in higher education and local industry dynamics. We take the output is produced for the international market which means there is no limit on the size of the market and large number of firms can enter. The technology brought in by TNCs at time To is similar to a scale effect in the production. This in turn engenders a dynamic process of growth. The kind or level of technology brought in by TNCs is a function of number of skilled workers and their level of skills at time To. The higher-end technology like investing in research and development causes higher degree of spillovers than low-end operations of TNCs such as data feeding and coding operations.

In Romer's (1990) model, spillovers of knowledge are main source of increasing returns to investment in human capital and research and development. This takes place owing to two main characteristics of innovations i.e., nonrivalrious and non-excludability conditions. Nonrivalry implies use of a new technology or a blueprint (or a new idea) does not preclude others from its use- there can be a simultaneous use by large number of agents. Larger the number of users larger is its aggregate value. International trade and investment increases the number of users. The non-excludability implies a new technology can not be fully appropriated by an innovator owing to spillovers and possible imitation by other agents in the economy. Human capital accumulates partly due to spillovers associated with the nature of the

\footnotetext{
5 As shown by Romer (1990) nonrivalry has two important implications for the theory of growth. First, nonrival goods can be accumulated without bound on a percapita basis, whereas a piece of human capital such as the ability to add cannot. Each person has only a finite number of years that can be spent acquiring skills. Secondly, a nonrival good besets knowledge spillovers that is incomplete excludability. These two features of knowledge- unbounded growth and incomplete appropriability- cause long run sustained economic growth.
} 
technologies brought in by TNCs and also deliberate efforts of TNCs in training and investing in education in the local industry and their linkages with local firms and input industries.

Proposition 1: Export oriented TNC cause higher spillover effects. Export markets relax domestic market size constraint and facilitates entry of large number of firms. Larger the number of firms higher is the spillover effect because larger number of TNCs brings in differentiated inputs and technologies of both the rivalrious and non-rivalrous kind. This in turn leads to higher to degree of spillovers to local industry and workers. Secondly, different TNCs train local workers on different technologies, which increases diverse range of skills.

Proposition 2: Following from the above observation, larger the number of firms higher are the incentives for workers to acquire both general and specialized skills. A small market size restricts number of firms to a few (especially if there are economies of scale). This in turn can give monopsony power to firms which makes them pay skilled workers wages at par with unskilled workers. This discourages skilled labor to acquire specialized skills (Rotemberg and Saloner, 2000). Export orientation increases the market size and facilitates a large number of firms to enter the industry.

Proposition 3: Export oriented firms forming into a cluster cause faster aggregate human capital accumulation. High-tech industry cluster engenders agglomeration economies, which contributes to aggregate human capital accumulation. Agglomeration economies imply that for given inputs the output of an individual firm is larger is the aggregate output of other firms producing the same good in the same region. Export orientation relaxing the market size constraint increases the number of TNCs and local firms in a cluster. Increase in number of firms in a cluster enhances agglomeration economies. The cluster activity increases spillovers effects of diffusing technologies and new ideas with ease because concentration of large number of a high tech industry within a geographic region. This is especially more dominant if knowledge is tacit and uncodified (Baptista, 2000) which requires close interaction among skilled workers. Mobility of workers is easier in a cluster because costs of job search are lower owing to 
presence of large number of firms with complimentary skills. A cluster also facilitates firms to hire workers with experience and skills more suitable to the requirements in the context of rapid technological changes. Mobility of skilled and experienced workers facilitates free flow of new ideas and knowledge, which in turn increases aggregate human capital formation (Saxenian, 1996). Cluster also facilitates contracting out work to other firms depending on their complementary skills. The inter-firm linkages and cooperation increase spillovers. This is especially dominant if firms in the cluster are not competing for the small local market but are international trade oriented. This becomes even more significant if TNCs and local firms in the developing country are not competitors but have complimentary skills, which increases joint collaborations and cooperation between local firms and TNCs.

Proposition 4: Following from the above observation, larger forward and backward linkages of TNC with the local industry cause higher level of spillovers than TNCs operating as islands in a developing economy. Backward linkages involve linkages with human capital generating institutions such as universities, research labs and with firms that produce complimentary inputs and services. Forward linkages for an export oriented high-tech industry in a developing economy involve linkage with the home and international market operations of TNCs. A TNC with no backward linkage operates like an enclave and it generates limited spillover effects. A TNC that builds effective backward linkages stimulates further investment and development (Kobrin, 1999) and generates knowledge spillovers in technology and organizational practices.

Proposition 5: Larger the technology gap between local firms and industry, lower is the realization of knowledge spillovers (Blomstrom and Sjoholm, 1999). There are two public goods in the system- the knowledge spillovers and the government investment in higher education and research and development. For private firms to utilize and absorb this knowledge, they have to make their own private efforts in research and development and training of employees (Cohen and Levinthal, 1989, Coe and Helpman, 1995, Kokko, 1996). In a developing country in which there are market failures in investment in research and 
development by private agents owing to inefficient market institutions ${ }^{6}$ spillovers from TNCs operations can be turned into effective public goods, if government matches it with its investment in public goods of higher education and research and development. In other words, government investment increases the absorbive capacity of the local industry. This can be more effective if it is done in cooperation with the private firms.

Proposition 6: TNC investments in the lower-end technology in a developing economy contribute negatively to human capital accumulation. Low wage cost of skilled labor facilitates TNCs to invest in lower end services, which leads to misutilization of human capital stock in a developing economy. This is similar to Romers (1987) argument that an increase in the total supply of labor causes negative spillover effects because it reduces the incentives for firms to discover and implement labor saving innovations that also have positive spillover effects on the production throughout the economy. If the cost of skilled labor is a lot lower than it prevailing in developed economies, TNC set up operations for the lower-end operations in developing countries. Lower-end technologies have low level learning economies on the job and also exhibit lower level of knowledge spillovers. This would lead to a net loss to the economy, if the similar skilled labor can be used in other activities with higher learning economies but similar or slightly lower current wage rate. In other words, TNCs by paying a slightly higher current wage than other sectors with higher learning economies can crowd out the other sectors, which have higher potential contribution to growth.

To recapitulate proposition 1 , the above result has to seen in terms of market structure dynamics. If there are only a few firms and large supply of skilled labor, there is likelihood the skilled workers would be

\footnotetext{
${ }^{6}$ Romer (1990) observes that that little human capital can be devoted to research is that research produces an input that is purchased by a sector that engages in monopoly pricing. The markup of price over marginal cost forces a wedge between the marginal social product of an input used in this sector and in market compensation.
} 
utilized sub-optimally. As more firms enter the market, demand for skilled labor increases, which puts upward pressure in wages. This in turn induces firms to utilize skilled workers more productively.

\section{Determinants of FDI in India's Software Industry}

As mentioned in the section on theory, the initial endowment of human capital stock in the base year (To) determines entry of TNCs into the local industry. It also determines the nature of TNC operations in terms of technology they bring in and their backward and forward linkages with the local industry and firms. Earlier, we have simplified it in terms of human capital stock. In the following, we discuss several other determinants apart from the labor market conditions, taking them as the initial conditions. In the later section, we trace out the contribution of TNCs to human capital accumulation and the other factors.

The primary motive for FDI in developing economies is to serve the growing local market and take advantage of low cost skilled and semi-skilled labor for the international market. Software products are information goods for which research and development and marketing costs are high but marginal costs of reproduction are close to zero (Shapiro and Varian, 1998). Therefore in the case of software products, local production is not necessary for serving the local market irrespective of large market size because the transportation costs and marginal costs of reproduction of software products are close to zero. If the motive of TNCs is primarily to serve the local market they open sales and service offices for serving the local market. TNCs investment in the software development centers in a developing country would be primarily to take advantage of low cost skilled labor for software development and support of home operations. ${ }^{\square}$ But

\footnotetext{
${ }^{7}$ The interesting aspect of the industry- there is two way flow of FDI. Large IT firms from the US and Europe invest in India for software programming and coding and research and development. Large Indian IT firms, invest in the Europe and the US for customer development and software consultancy services. The later part could be through both standalone units and joint ventures of Indian firms with the major TNCs.
} 
in the case of software consultancy services, and segments such telecom related software development, local market size is an important determinant of TNCs investment.

Endowment of low-cost skilled labor on its own would not result in FDI and its contribution to the development of the local economy. For TNCs to take full advantage of skilled manpower and contribute to its endowment, the endowment of skilled labor has to be supported by efficient market institutions, the government policies, and local technological institutions such as the universities and research institutions. In the following, we illustrate these factors that govern TNCs investment.

The pattern of TNCs' investment in India's software industry can be broadly segregated into three broad groups: offshore software development (programming and coding) and investment in research and development and IT enabled services such as medical transcripts, back office operations, call centers, data processing etc. In more elaborate level, the pattern can be observed in terms of the segments such as Integrated Circuit Design (IC), Systems Software, Application Software, and Communication software. In the case of IC, both semi-conductor and related software development takes place. ${ }^{8}$ These different segments require different levels of labor skills and sophistication. The IT enabled services is the least skill intensive part and programming and coding requires basic skills while the other segments require highly specialized skills. For example, in the case of telecom related software development, the skill requirements are high because it is necessary to have software skills and also understanding of telecom technology which is subject to rapid changes. Many software products include sophisticated mathematical algorithms used in data compression for telecommunications.

In the case of coding and programming, the waterfall model shows the requirement analysis and design will be done in the home and coding is done in Indian operations to take advantage of the low cost skilled labor

\footnotetext{
${ }^{8}$ The following are the examples of major TNCs in the different segments in the Indian industry: in ICTexas Instruments, Siemens, Phillips, Synopsis, Analog Devises, National Semiconductors; in Systems Software- Oracle, Novell, Sun Micro Systems, Digital, Apple; in Communication Software- Lucent Technologies, Nortel, Siemens, Motorola, Cisco Systems, Ericcson, and Sony.
} 
(Ghemawat, Patibandla and Coughlin, 1999). It is done either by TNCs subsidiaries or by joint collaboration with local firms. In the case of research and development- TNCs operate both at the low-end and high-end R\&D. At the lower-end of R\&D, TNCs could get into joint collaboration with local firms by subcontracting out the work. At the higher-end, most of it is done in-house in the Indian subsidiaries with the R\&D teams linked with home and other foreign operations. In telecom related software, TNCs such as Nortell got into joint ventures with large local firms for R\&D to make use of the complimentary skills of the local firms at low costs under carefully formulated contracts for protecting intellectual property rights (Basant and Chandra, and Mytelka, 1999). As mentioned before, in the case of Telecom related software development both comparative advantage in low cost skilled labor and also the growing local market is the motives for MNC investment.

\subsection{The Labor Market}

Endowment of the skilled labor at the different levels determine the pattern of FDI in this industry and their nature of operations which in turn has implications on the evolution of the industry. The labor market dynamics in terms of supply response to changing demand and technology conditions is the crucial determinant of TNC investment. The labor market demand can be segregated into the following segments: the international component or brain drain to the US and Europe, demand from the TNCs and large domestic firms which are mostly export oriented, and the small firms catering to local market needs. These segments are at different levels of skill intensity.

The higher-end skilled professionals graduate out of the half a dozen Indian Institutes of Technology, which are of international standards in engineering education. Apart from this, there are hundred of regional engineering colleges at the state level. There are about 200 universities that provide bachelor and masters degrees in computer science. At present there are a large number of private training institutes that provide industry oriented short term and long term training to students 9 By 2001 all these institutes generate about 75,000 to 80,000 software professionals of varying skills annually. Out of this about 16,500 engineering graduates are produced by the formal institutions and the rest by the private training institutes. 
There are about 2,300 recognized private training institutes in the country. The large training firms such as NIIT and APTECH account for about 60 per cent of the market share of the private training. These institutes are tuned with emerging trends in the technology and quickly offer the courses in tune with prevailing demand conditions. The larger institutes have $R \& D$ departments, which undertake research on the emerging technologies and market needs with specialized professionals. These professionals quickly train the teachers on these technologies and offer the relevant courses. These institutes offer a wide range of short term and long term courses. This type of training can be considered to meet the short-term needs of the market.

In the recent years, the government of India has set up Indian Institutes of Information Technology in major cities such as Bangalore, Hyderabad, and Delhi in collaboration with large Indian software firms and TNCs such as Microsoft and IBM. The ministry of information technology has announced setting up of these institutes in all the major cities in the countries (Nasscom Website). These institutes are expected to impart highly specialized training. The waterfall model showed the basic designing is done in the US and programming and coding in India. The IIITs are expected to rectify this by providing high-end training on popular design engineering products. Furthermore, the Software Engineering Institute has been set up in Bangalore as a joint venture between Indian Institute of Science, the government of Karnataka, LG Soft India and the Center for Information Systems Engineering of the Carnegie Mellon Research Institute for Information Systems Engineering. This institute offers the most advanced training in software engineering. India has about four premier management schools of world standards and several hundreds more producing management graduates. The top four schools produce about 1000 management graduates annually of high standards. Most of these graduates tend to have their first (bachelors) degree in engineering. These management graduates are highly beneficial for software firms, as they could understand the technology and commercialization of technology and business processes and organization and time management. Software consultancy services require not only understanding of technology but also financial management and business concepts. In other words, the management graduates are a good source for project managers of high technology commercialization.

\footnotetext{
${ }^{9}$ Large private firms in IT training are NIIT, APTECH, Tata Infotech, SSI, and STG followed by players
} 
One of the other important aspects of the labor market that works in favor of TNCs is the large-scale inhouse training by the Indian large firms. On the basis of formal higher education and diploma training of graduates, Indian large firms impart in-house training in software related skills. For example, the largest Indian firm, Tata Consultancy Services has been investing about 10 per cent of its revenues on training manpower. Other large firms such as Infosys, NIIT, and Wipro invest significant amount on in-house training of employees. A large portion of these trained employees are attracted away by the TNCs in India and by the job market in the US and Europe. Especially employees with a few of years of experience as project managers are attracted away by the TNCs in India with highly attractive pay packages. As most of the training by the local firms is on general software skills, labor mobility across firms is easier. As the labor economics has shown, the more general is the on the job training, the mobility of trained workers is higher (Becker, 1964). This advantage of attracting highly skilled workers gets magnified in the presence of technologically dynamic clusters as the cluster activity reduces the transaction costs of labor market significantly (Saxenian, 1996). In India's case the software industry cluster in Bangalore supplies an attractive labor market to TNCs for their investments.

In the waterfall model of software development in which the output of one is the input to the other, the time zone difference between India and the United States provides an additional advantage to TNCs in the labor market in terms of organizing 24 hour employee shifts. This is especially important in the context of highly advanced communication infrastructure, which makes transfer of huge data across the borders at low cost and high speed.

\subsection{Local Technology Institutions}

Endowment of effective technology institutions compliments the skilled labor advantage significantly. They will not only generate skilled workforce but also facilitate research development. Well-developed universities and research institutes facilitate TNCs to sponsor research and make use of the existing infrastructure for their research and development. Secondly, it helps them to promote their platforms, train people on their technology platforms. As mentioned earlier, under the past policy of import substitution the government of India made large-scale investments in science and technology. This led to creation of

such as IBM, CMC, Petasoft and Datapro. 
advanced engineering institutes, science institutions such Indian Institute of Science in Bangalore and the public sector firms such Bharat Heavy Electronics which undertake high level research and development. For example, Bangalore became a dynamic software industry cluster because it has Indian Institute of Science, fourteen engineering colleges, and the large state-owned defense and communication industries including the Indian Telephone Industry, Hindustan Machine Tools, Hindustan Aeronautics, Bharat Electronics, and Bharat Earth Movers were established in the city during the 1950s (Balasubramanyan and Balasubramanyan (1999).

The number of consultancy organizations and consultants in India now well over 4000 with annual turnover of Rs 10000 million which include consultancy exports as well. Over 100,000 specialists are employed including nearly 10,000 management consultants. The wide spectrum of disciplines and services provided by Indian consultants range from project identification to commissioning involving supervision and training personnel, market surveys, rehabilitation of sick units as well as operation and maintenance. The consultancy organizations in India are directly or indirectly supported by more than $1000 \mathrm{R} \& \mathrm{D}$ institutions and research laboratories both under CSIR as well as other major scientific organizations such as DRDO. Major financial institutions such as IDBI, IFCI and ICICI have also promoted the use of consultants by establishing state level consultancy organizations. Indian consultancy capabilities are strong in several areas such as civil engineering and construction, telecommunications, power, metallurgy, chemical, petrochemicals and computer software. The government through appropriate policy measures for growth and development is further strengthening the capabilities of Indian Consultancy Organizations and Consultants. The Consultancy Development Center, an autonomous organization set up by the Department of Scientific and Industrial Research, Ministry of Science and Technology, Government of India is fulfilling these needs by providing variety of services for consultants and entrepreneurs, including databases and by developing norms, guidelines and ratings of Consultants (Commonwealth Science Council, 2000)

\subsection{Dynamic Industry Clusters}


Another important determinant of pattern of FDI and its implications for human capital accumulation is presence of technologically dynamic industry clusters. Comparative advantage in the endowment of skilled labor in a developing economy can get magnified if specific industries are organized in terms of technologically dynamic clusters by external economies of cluster activity. Low cost skilled labor combined with external economies of cluster activity is highly attractive for FDI in high-tech industries. The software industry cluster in Bangalore presents the case where large pool of software engineers and programmers and their productivity appears to have been enhanced by the organization of the industry into a technologically dynamic cluster in Bangalore. It has provided strong advantage for MNC investment in Bangalore.

Porter's (1990) theory of clusters characterizes technologically dynamic clusters in developed economies. It shows the micro-economic underpinnings of innovation in country-specific industrial clusters: this relationship depends on subtle interactions between input supply and local demand conditions, the presence and orientation of related and supporting industries, and the nature of local competitive rivalry. In developing countries, technologically dynamic industry clusters could be mainly export driven owing to low costs of skilled manpower (comparative advantage reasons). In such a case, local competitive rivalry is not a necessary condition. For example, the software industry cluster in Bangalore, India is export driven with minimal domestic market (Ghemawat and Patibandla, 1999). Most TNC have set up development centers in Bangalore for supporting R\&D activity in home base and for software development for global market. Given the focus of this paper, the germane point is that TNC investment in Research and

\footnotetext{
${ }^{10}$ The large pool of skilled workers in the southern part of India, the Indian institute of Science and the high-tech public sector firms and entry of Texas Instruments and Hewlett and Packward in the mid eighties and the government support of infrastructure in terms of Software Technology Parks contributed to the emergence of Bangalore as an effective cluster.
} 
Development in India's software industry is motivated for taking advantage of low cost of skilled labor and also the strong external economies of a dynamic industry cluster.

\subsection{Development Level of Local Industry and Firms}

Technological development level of local industry and firms is one of the important determinants of TNC investment in a high-tech industry in a developing economy. Entry through joint ventures with local firms might be necessary for TNCs to acquire the knowledge of the local economy and avoiding investment in sunk costs for keeping exit option open. If the technology lag between local firms and TNCs is too large, it does not facilitate joint ventures. Secondly, joint ventures with well-developed local firms reduce the cost of installing additional infrastructure. For example, the case of Nortel in telecom-software and its joint collaboration with the large highly developed Indian firms such as Infosys and Wipro and TCS illustrates this point (Basant, Chandra and Mytelka, 1998). Matured local firms provide complementary skills. Furthermore, it makes labor market dynamic- large number of highly developed firms provides workers to acquire both general and specialized skills. This in turn could cause mobility of skilled workers across firms facilitating technological dynamism as illustrated by Saxenian (1996) for the case of the Silicon Valley Cluster. The highly developed local firms facilitate TNC investment both at the lower end and higher end Research and Development in India's software industry. It leads to an effective process of technological collaborations between TNCs and local firms and among TNCs themselves.

\subsection{Domestic Market Size}

As mentioned earlier, in the case of software products the domestic market size is not an important determinant of FDI for production because in the case of information goods marginal costs of reproduction and transportation costs are zero. TNCs would basically set up sales offices to serve the local market. Similarly in the case of semi-conductor chips the transportation costs are negligible. If TNCs invest in production of these goods in a developing economy, it is basically to make use of low-cost skilled labor for

\footnotetext{
${ }^{11}$ An interesting aspect of the Indian industry is TNCs such as Oracle collaborates with AT\&T, and Nokia for development of telecom related software development in Bangalore.
} 
their home and global production operations. However in the case of telecom related software development and software consultancy services, the size and growth potential of the local market becomes an important factor for FDI in production of goods and services in the local market. TNCs in the telecom related software such as Motorola and Nortel initially entered mostly for the making use of the skilled manpower for their home operations. In the recent years, the rapid growth of telecom market prompted them to expand their operations by including the local market into their calculations. One of the other possible factors for TNCs investment in developing economies in the software industry could be technology lock-in strategy of leading TNCs. Several software products have high switching costs to consumers once they are trained on the technology, which locks them into the technology (Shapiro and Varian, 1998). For example, despite large scale copy right violation of Windows operating system in China, Microsoft invests in China for locking-in large number of future customers (Patibandla, 2001).

\subsection{The Policy Factors}

The policy factors regarding openness to international trade, taxes and incentives, macro economic stability (exchange rate), infrastructure support and regulatory transparency and predictability are important determinant of TNC investment. As mentioned earlier, India followed a general import substitution policy till the early nineties, which put restrictions on imports and overvalued exchange rate a disincentive to exports. In 1984, the policy towards the software industry was made highly liberal in allowing 100 per cent owned TNC.subsidiaries, imports of hardware and software (Heeks, 1996). The early nineties allowed duty-free imports of hardware and software. Foreign direct investment in this industry is highly encouraged by the tax incentives- no corporate income tax on exports. Furthermore, the government of India provided infrastructure support to the industry in terms of setting up of Software Technology Parks in major cities, which provided the industry with telecommunications infrastructure, power and roads and rapid clearances of the FDI proposals, and support for imports and exports.

STPIs provided not only the infrastructure necessary for exports but also procedural assistance such as project approval imports approval, boding and export certification. STPI at present has 19 centers in the 
country. Over 6,400 units are registered with the STPI, an autonomous society under the ministry of information technology. STPI has set up a business support center in Silicon Valley to assist Indian firms and the US companies wanting to invest in India. By 2000-2001, the exports from the SPTI amounted to about $\$ 4.3$ billion dollars- close to 80 percent of total software exports from India.

In 1991, a series of promotional measures such as reduction in telecommunication charges for satellite links, duty free imports of telecommunication equipment into export processing units, excise duty exemptions, income tax exemptions on exports were implemented. Duties on software imports, which previously were at 110 per cent were reduced to 10 percent in 1995 and were eliminated in 1997 . In the mid-nineties, the ministry of information technology was created in order to promote the industryproviding information and support to TNC investment. Until recently, the Internet connections in the domestic market are a public sector monopoly of VSNL (Videshi Samchar Nigam Limited). This kept the costs of Internet high and bandwidth low in the domestic market. Recently, the government has opened the Internet connection to the private sector. However the general infrastructure support in India remains inefficient.

\subsection{The Market Institutions}

The market institutional factors such as property rights and transaction costs are important determinants of FDI in high-tech industries in developing economies. In the case of high-tech industries, the intellectual property rights of the copyright act are extremely important. As mentioned earlier, software products are information goods for which marginal costs of reproduction are close zero, which makes pirating, or counterfeiting very easy. The Indian copyright act of 1957 is based on the Berne Convention on Copyrights. However the enforcement had been very weak till recently which caused wide spread counterfeiting. Till then most TNC came to India primarily to make use of low cost skilled workforce for software development for parent operations. The act was amended in 1995 to make it on par with the most modern law in the field under the initiation by the software industry association, NASSCOM. In the recent years, India's software industry association (NASSCOM) in cooperation with the government agencies undertakes the enforcement of the act (Ghemawat, Patibandla and Couglin 2000). The growing importance of the domestic software industry provides an incentive to the government to undertake enforcement in an effective manner. Consequently, it 
provides the necessary institutional conditions for TNCs to invest in India for software development for the global market, Research and Development and for serving the growing local market.

If the prevailing institutions in a specific country cause the transaction costs of contracts very high, it will discourage FDI in these industries. Transaction costs are higher when it is highly costly to understand and foresee contingencies and to formulate contracts in a clear manner. Furthermore, there have to be effective judiciary to monitor and enforce the contracts (Williamson, 1985). The importance of formulation and enforcement of contracts is important when TNCs get into joint ventures with local firms in software development. Given the technology and intangible assets intensity of the products, the technology can be appropriated by local agents. Although, the Indian judiciary is independent body, the process of resolving disputes involves high market transaction costs. So far, the collaboration between local firms and TNCs appear to be based on mutual understanding and trust rather than legally formulated contracts.

One of the institutional factors behind the investment by MNC in high-end R\&D is the democratic institution in which the governmental interference in the technological activity is absent. Investment in high end $R \& D$ requires a degree of secrecy and protection from leakage. The manager of a large MNC (Motorola) which has set a large R\&D center in Telecom related software development in Bangalore explained to us in the field interview that India's democratic institutions protect from the hazards of interference from governmental institutions and leakage of $R \& D$ secrets.

\subsection{Informational Imperfections and the Ethnic Network}


Informational factors and knowledge of the local institutions are important determinant of FDI in developing economies. If the costs of information collection and gaining institutional knowledge of the local market are high, it discourages FDI. In the case of India's software industry, the Ethnic network of overseas Indians appears to have reduced these costs and encouraged the flow of FDI. As mentioned earlier, there has been a large-scale brain drain of skilled workers to the US and the Western Europe. In several of the large American high tech companies, Indian skilled workers hold high level of managerial positions. These managers contributed to providing the knowledge about the potential of the Indian industry and institutional conditions and influenced the entry of TNCs. A good example is the case of Texas Instruments. The entry of Texas Instruments to India in 1985 was facilitated by the senior vice president in the US operations who happened to be from India.This was despite the image of Indian economy at that time that it was difficult to do business in India owing high level transaction costs and the government bureaucracy. Similarly is the case of Hewlett and Packard, Oracle and Nortell etc. Once the Texas Instruments and other first entrants succeed in their operations, they gave a demonstration effect to other large American and European companies to enter India.

Nearly 40 percent of the Silicon Valley startups in the 1990s have at least one Indian origin (Business Week, December 7, 1998). Most of them educated in the most elite technology universities of their home countries. As Saxenian (1999) observes, these ethnic immigrant entrepreneurs have continued reliance on traditional ethnic networks within the region (the professional groups such as The Indus Entrepreneur) alongside a comparable reliance on technologies that allow them to be connected to individuals, businesses, and regions anywhere in the world. This network contributed to TNC investment in the India's software in a significant way.

\section{Contribution of FDI for the Evolution of the Industry}


The propositions developed in Section 2, are tested on the basis of qualitative information and data collected from our field interviews of executives of a sample of TNCs and Indian firms in Bangalore and Hyderabad and Delhi. Later we undertake econometric testing of the hypotheses on the basis of firm level panel data.

\subsection{The Analysis of Qualitative Information of the Field Study}

To understand the contribution of TNCs to human capital accumulation qualitatively, we need to observe their nature of operations. In the following, we discuss a few case studies of TNC operations in India, drawn from our field interviews of managers of a sample of firms. To recapitulate, the field study covered 30 firms located in Bangalore, Hyderabad, and Delhi. It is based on two sets of extensive questionnaires one for TNC subsidiaries and the other for Indian firms. The main focus of the questions for the TNCs are for understanding their level of technology of their operations, backward and forward linkages with local firms and educational institutions, human resource practices, and their plans for growth and technology upgradation in the Indian operations. The main focus of the questionnaire for local firms is on the issue of the benefits with their collaborations with TNCs, skilled employee mobility and attrition. The interviews were conducted with one and in few cases multiple meetings with the senior managers. In the following we discuss a few case studies. This is done to bring out certain broad general pattern of the nature of their operations and its implications on human capital accumulation and the growth of the industry.

As discussed in the Appendix 1 of the background of the industry, India's software industry started at lowend level of data feeding and coding and has been moving up on the quality ladder. In the initial years of the early and mid-80s, several companies from the West outsourced and set up units to undertake low-end work of data and coding and programming owing to low cost of large pool of skilled labor. However, over time, the market structure dynamics changed owing to large number of entrants both TNCs and local firms into industry doing high end RD. Entry of Texas instruments in 1985 started the process of the change. 
The subsidiary of Texas Instruments (TI) was set up in Bangalore in 1985. It was made possible by the initiative taken by the then Indian Prime Minister, Rajiv Ghandhi. Apart from this, one of the senior vice presidents of TI happened be an Indian expatriate (Mr.Mohan Rao) who made the setting up of the subsidiary possible. At that time, the government did not permit private firms to own and install their own satellite communication facilities. The TI's managers brought in the most modern communication equipment (a 64 khps data link which has been increased to a much larger scale at present) and gave it to the government (the Department of Telecommunications) and got the link from the Department for their

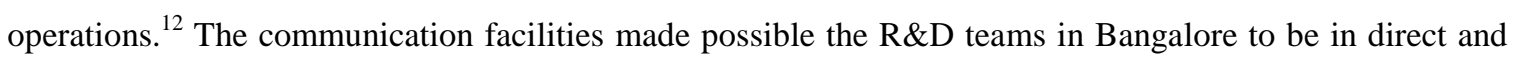
instant link with the parent operations in the US. The excess capacity on the statelite link in the beginning allowed local firms get the link and facilitate their movement from onsite projects to offshore development. It has been mostly export oriented in terms of supporting the $R \& D$ work at the parent and their global $R \& D$ teams in countries such as Israel.

The TI subsidiary recruits high skilled labor through rigorous screening from the IITs and regional engineering colleges and the Indian Institute of Science. It has strong human resource practices in terms of flat organizational structure and team and individual based incentives for promotion. The employees are given stock options. Once recruited, employees are given on the project training. Due to its HR policies, the attrition rate is observed to be at 15 percent below the industry average of 30 percent. Since the R\&D is done at a very high level of learning on the job to employees is very high. ${ }^{13}$ Secondly, because of its highend R\&D which requires strong synergy between different departments of chip designing and chip related software development it concentrates its work in one unit in Bangalore.

It developed strong linkages with the universities and research labs in and around Bangalore. It funded establishment of research labs in about 20 universities. It works with the professors in designing and

\footnotetext{
${ }^{12}$ At this time the idea of Software Technology Parks was formulated to provide the statelite and other insfrastructure facilities to software exporting firms.

${ }^{13}$ The Digital Signal Processor (DSP) chip was developed independently by the TI's subsidiary in Bangalore and it has been globally marketed.
} 
upgrading the curriculum of engineering education. It is stated to be a very important element of its linkage with educational institutions as in several universities the curriculum is outdated. As it does high level $R \& D$ in chip designing and digital signal processing, it does not outsource its work much to local firms. It has some outsourcing to four or five firms for short term projects for which TI does not want to hire people. The subsidiary, which started with about 23 engineers, employs about 500 highly trained engineers at present. According to the executive, it has plans to increase its operations to 1500 high skilled workforce in three years and offloading most of the R\&D work to the unit in India. The main reason is large pool of skilled manpower available in India and presence of highly sophisticated technological institutions such as Indian School of Science in Bangalore.

The two main immediate contributions of TI are the spillover effects to local firms. The TI operations with most modern communication links helped some of the large local firms such as TCS, INFOSYS and Wipro which are located in Bangalore to imitate TI s practices and move towards offshore development. Secondly, TI 's successful operation in India gave a demonstration effect to other American and European IT firms to look at India positively to set-up high end Research and Development Centers. This in turn caused further new entry, which had significant implications on the market structure dynamics and human capital accumulation.

Hewlett and Packard started its operations in 1989 in Bangalore with about 10 people ${ }^{14}$ At present, it employs about 1100 engineers. It has major plans for expansion. It has two types of independent operations: one to for software development and core Research and Development and the other is to market and sell H\&P computer hardware in the growing Indian market. It has a duplicate R\&D center in the city of Chennai (Madras) which was set up for active collaboration of research and development with the large Indian firm TCS (Tata Consultancy Services). H\&P in India follow a very active and effective backward linkage policy with both local firms and the research institutions. It has developed strong tie-ups with both

\footnotetext{
${ }^{14}$ Its coming to India is also partly responsible to a senior vice-president who is an expatriate Indian in its US unit.
} 
large Indian firms (TCS) and also about 25 small firms. Its unique outsourcing model consists of three types as explained by the executive during the field interview: (1) outside specialists, (consultants etc), who are brought-in regularly work on special projects for short duration: (2) out-tasked- an Indian firm would be given a site in H\&P to move in and work on a project and (3) outsourced - in which the project moves out to an India firm. These different models are adopted depending on the project needs.

It outsources some projects to a group of small companies who are selected under rigorous screening and bidding and are made to sign non-disclosure contracts. The firms are provided with H\&P technology and some training to the employees. It deliberately selects small firms because entrepreneurs of small firms are highly motivated because their linkage with $\mathrm{H} \& \mathrm{P}$ is a strong source for establishing their standing and for growth. ${ }^{-5}$ Some of the problems it faces in outsourcing are delivery time, cost overruns and attrition issue of employees on a given project. In order to mitigate these risks some times it employs more than one firm on a similar task. Its operation in the Bangalore cluster facilitated its linkage with technologically strong small firms and its growth through partnerships with the local firms. This in turn results in strong spillovers to local firms and human capital accumulation through active movement of skilled workers.

The H\&P subsidiary in Bangalore developed a strong linkage with the Indian Institute of Science in Bangalore for its R\&D activities. Furthermore, it funds research in selected universities in and around Bangalore. It helps the selected colleges and universities in developing course curriculum, and elective courses. It has programs for training teachers $\frac{16}{\text { in }}$ these colleges. It has plans to expand its direct involvement in education and training.

\footnotetext{
${ }^{15}$ One of the small firms, H\&P supported in Bangalore has developed a product for internet technology and has become very successful.

${ }^{16}$ According to the executive, one of the problems of labor market is the shortage of good teachers of information technology skills as most skilled teachers are absorbed by the industry offering higher salaries than the universities.
} 
Primary motive to invest in R\&D center in India is to make use of large pool of skilled personnel. Engineering graduates are recruited from the Regional Engineering Colleges. H\&P impart them with six months of rigorous in-house training. Human resource practices in terms of flat organizational structure, operational freedom and strong employee incentives are provided for employee job satisfaction, which keep the attrition rate low. Employees incentives are very strong not only in terms of profit sharing but also employees are allowed to patent their research. During the last three years, the employees of H\&P in India made about 60 patent registrations. Regularly 15 to 20 percent of its employees travel to the US and other countries (such as Israel) where H\&P has R\&D centers which is a strong source for reducing idea gap and increasing information externalities.

Oracle started its operations in Bangalore in 1994 to contribute to Oracle's global Internet strategy with design, development and maintenance of its products. At present it employs about 450 skilled personnel. It has plans to expand to $2000 \mathrm{R} \& \mathrm{D}$ personnel within the next five years. It has $\mathrm{R} \& \mathrm{D}$ centers in Bangalore and Hyderabad. The setup works on four groups- database, tools, education and platform technology division. The Bangalore centers concentrates on Data Based Tools while the center in Hyderabad focuses on Application and Systems Development. The multiple centers are set up to tap into local skill pools and make use of infrastructure and state government support. The primary motive for coming to India was parent unit's experience with the Indian skilled workers in the US and the demonstration effect from Texas Instruments and H\&P operations in Bangalore. The primary motive for setting up the R\&D center, according to the CEO, is not cost saving but to make use of high quality and large pool of skilled labor in India.

Similar to H\&P, Oracle has two types of operations, which are independent of each other- (1) sales and marketing to serve the growing local market and (2) software development and research and development. In the first case, it is quite aggressive in promoting its technology with users in the Indian market- local consumers and firms with active tie-ups. Along with Microsoft and a few other TNCs it promotes teaching of Oracle platforms by getting involved in the setting up of Indian Institute of Information Technology. The R\&D work is to support of the parent's R\&D in the U.S. Secondly, the India center provides electronic 
support to Oracle's customers in all English-speaking countries. According to the executive, the quality of R\&D work done in India is comparable to the work in the U.S. Its development work does not undertake outsourcing with the local firms because of complexity of high level R\&D work. Specialists from the other firms and also consultants are brought in-house on project basis. Projects do not go out. Similar to Microsoft, Oracle does not adopt open-code programming. Therefore certain degree of secrecy involved. However, the development center in Bangalore collaborates with the other TNCs in India such as AT\&T and Nokia for developing telecom related software.

The skilled personnel are recruited with rigorous screening from selected universities and engineering colleges. Four to six months of rigorous training is provided. Providing job satisfaction with challenging is the primary objective of its $H \& R$ policies. The best skilled people are attracted to Oracle because of its international brand name. Some of the skilled personnel are regularly sent to the parent in the US for training and coordination of the R\&D work. The skill deficiency in India is lack effective product management skills, which the Oracle subsidiary imparts to its employees in cooperation with the Indian Institute of Management in Bangalore. It has research linkages with Anna University, IIIT Hyderabad and IIM Bangalore for sponsoring research and training of skilled labor.

The following observations regarding Microsoft's operations are based on the secondary information because despite numerous attempts by us, the executives of the development center in Hyderabad refused to meet us on the grounds of secrecy of their operations. Microsoft started its operations in 1987 mainly to sell its products and services in the Indian market. Although the market from consumers for the Microsoft's operating systems was small, the growing Indian software industry for developing software programming for the international market has provided large potential market from the Indian firms. Secondly, the lockin characteristics of its platforms provided an opportunity for Microsoft to lock-in Indian firms into its technology thereby promoting its products globally. Thereby Microsoft undertakes quite active and aggressive approach in getting collaborative arrangements with almost all the leading Indian firms. It's sales operations, but not the R\&D center in Hyderabad, which actively invest in education to spread Microsoft's technology. This is very unlike Texas Instruments, which does not have any local market focus. The website of Microsoft-India shows that Microsoft provides certified technical courses at 
Microsoft authorized Technical Education Centers (ATEC) and end-user training courses on Microsoft products via Authorized Training Centers (ATC). Furthermore, it says that Microsoft seminars and handson, lab based and video courses emphasize skill transfer by providing the necessary technology, and help to build, implement, and support real-world business solutions that take full advantage of Microsoft Technology. It also involved in the course development in the IIIT in Hyderabad. The R\&D center in Hyderabad is closed operations without any outsourcing or collaborations with the local firms.

Motorola started in operations in Bangalore in 1991 with 50 employees. At present the subsidiary has about 1,300 employees out of which about 1000 are in software development and chip designing, mostly telecom related. At present it has operations in three cities in India, Bangalore, Hyderabad and Gurgaon (adjacent to Delhi). According to the executive interviewed, the Bangalore center is of the state of the art technology concentrating at high-end R\&D while the center in Hyderabad has been set up to tap into local labor market for lower end software programming and coding. Its operations in Bangalore developed strong backward linkages both with local firms and educational institutions. It has three types of projects: (1) high-end R\&D projects are kept in-house with high-degree of secrecy, (2) bring in specialists from outside for short period for specific projects and (3) subcontracting out the project to Indian firms. There are about 15 Indian firmsboth small and large- with which it has developed subcontractor relations. The firms are provided with training on Motorola's technology and project management. According to the executive interviewed they see a rapid growth in outsourcing to local firms, especially to small firms which are carefully identified. Furthermore, it invests significantly in universities and research institutions. After looking at 100 colleges in and around Bangalore, it shortlisted 15 of them. It provides them with technology and tools, and training to the faculty. It also brings in some of the faculty for sabbatical in Motorola's center. It has also invested in the courses of IIITs of Bangalore and Hyderabad. Fresh and highly qualified graduates are recruited from the colleges and universities and IITs and are provided with intense in-house training. After a few years of experience they provided with stock options.

\footnotetext{
${ }^{17}$ Since we could not secure the interview with the executives, we are not in position to bring out the qualitative information about its operations.
} 
Similar to Motorola, Nortel has operations in India for developing telecom-related software. However, its sequence of entry into India is different. As mentioned in the previous section, a technologically well developed local firms facilitates entry of TNCs through joint ventures and collaborations. Nortell entered India in 1989 through a joint R\&D collaboration with large Indian firms such as TCS, INFOSYS, WIPRO, and Silicon Automation Systems to make use of mutual complementary assets in technology, human capital and infrastructure. Once again, its initial entry was inspired by the success of TI and facilitated by a few Indian expatriate senior mangers in its parent unit in Canada. The partnership became possible because Nortel could formulate non-disclosure contracts by the each of its partners. In each partners location, Nortel created infrastructure, the state of art telecom hardware and large capacity for communications. It also invested heavily in training of the employees of the Indian firms. 1.8 As the partnership became successful, Nortel transferred more complex technologies to the Indian firms. The partnership benefited Nortel in reducing costs of developing telecom-related software significantly and the Indian partners in terms of transfer of latest technology and Nortel's international management practices and markets. One of the Indian firms, because of transfer of technology, has been able to develop a new product that could be globally marketed. As Nortell gained experience with the Indian market institutions through the partnerships, it has set up its own subsidiary in Bangalore in 2000.

Similarly, CISCO entered India through partnership with two Indian firms (WIPRO and HCL) in 1996 and then later 1998 set up their own R\&D center in Bangalore. At present it employs about 300 skilled personnel and plans to expand to 800 by 2002 with $\$ 150$ million investment. It developed backward linkages with the educational institutions and also local firms through outsourcing. It continues its partnership with the leading local firms such as INFOSYS, WIPRO and HCL for product development. It plans to set up 34 regional networking academies in the country in partnership with the government of India and educational institutions. It also set up a center for networking excellence in Bangalore in partnership with the ministry of information technology to promote advanced networking education. Apart

${ }^{18}$ Also see Basant, Chandra and Mytelka, 1999. 
from this, CISCO, which grew by buying up of companies, plans to provide venture capital to start up companies in India.

The following are some of the general patterns of the benefits to local firms from the tie-ups with TNCs on the basis of our field interviews of leading Indian firms such as INFOSYS, WIPRO, SATYAM and VISUALSOFT. In the initial stages, collaborations with TNCs give local firms a brand image internationally, which generates more customers. It provides access to international markets. If a local firm gets into tie up with a leading TNCs such as Microsoft to make compatible products of the TNC technology, then the TNC promotes the local firm internationally. There are hazards to local firms of being locked-in to the technology of TNC with high switching costs. In order to minimize these hazards, local firms gets into tie-up with several TNCs gaining access to each of the platforms. Some of the large Indian firms have tie-ups with a large number of TNCs. Furthermore, the collaborations provide local firms insights into the R\&D and management practices of the TNCs. In partnerships, employees (the project teams) receive training both in India and in the parent operation of the TNCs. The movement of the skilled workers to the developed economies exposes them to the latest technologies, ideas and practices. In the recent years, several Indian firms started acquire firms in the US and Europe. The experience with the joint collaborations with TNCs helped them to gain experience of the efficient management practices of the TNCs, which helps them in acquiring and running firms abroad easier.

Smaller Indian firms at the lower end of technology in India focus mostly on the domestic market in developing niche products and client services. In this case, leading TNCs such as Microsoft, Oracle has an incentive to provide free training and technology because these firms are instruments to spread their platforms in the Indian market.

The above discussion of the case studies provides qualitative evidence to the propositions listed in the Section 2. In the following we discuss the evidence with respect to the proposition 1 and 2 on the issue of the link between market structure, export orientation and human capital accumulation. As mentioned

\footnotetext{
${ }^{19}$ Venture capital funding by TNCs can be a significant element of evolution of the industry as TNC are
} 
earlier, till the mid-80s, a few American and European firms outsourced low-end software development to India such as data feeding, and coding etc. Given the large pool of skilled labor at low costs and a small number of firms with monopsony power allowed firms to use highly skilled labor to mundane tasks. The entry of Texas instruments in 1985 and its successful R\&D operation in Bangalore provided demonstration effect to other leading American IT firms to enter India for setting up of development center for supporting the parent companies operations. It gave a further fillip to the entry of both American and European IT firms to set up development centers. At present in the Bangalore cluster alone there are about 140 TNC development centers. They not only set up development centers but also expanded their Indian operations substantially. Simultaneously, several Indian firms came into the market grew rapidly mostly through exports to the American market. As discussed earlier, all most all the development centers of TNCs and Indian large firms are 100 percent export oriented to make use of the skilled labor in India for the international markets. The export orientation the firms relaxes the market size constraint and thereby facilitates entry of large number of large and small firms. All this has contributed to a rapid increase in demand for skilled labor with both general and specialized skills. Consequently, wage rate for skilled software professionals has been increasing at annual rate of 30 percent from the mid-90s. At present, there is an intense competition among TNCs and large Indian firms for skilled people with a few years of experience in project development and management. This has provided strong incentives for people to acquire both the general and specialized skills. The increase in demand for education led to private firms to enter the education market. From our interview with NIIT, a leading private IT training firm, it has plans for expansion even to smaller towns all over India. Apart from this, there has been increasing cooperation between the governments at the center and the state level and the leading TNCs and Indian firms to invest in higher education by setting institutions such as IIITs and expanding training in government institutions such as IITs and Regional Engineering colleges.

Furthermore, as illustrated earlier, most of the TNCs upgraded their operations in India to the technological frontiers of product development. For example, as gathered from our field study, several leading TNCs such as TI, Motorola, Nortell, Oracle, and Adope are working at the frontier of their technology in the 
Indian operations. ${ }^{20}$ To illustrate an example, the Indian subsidiary Adobe India of US-based $\$ 1.2$ billion Adobe System has developed Acrobat Reader for hand held devices from concept to the final product level at its R\&D center in Noida. This software increases the efficiency of hand held devices and one load large PDF files on the hand held devises. The technological higher end operations of the TNCs give higher learning economies in human capital accumulation. Several of the TNCs executives told us that one of the reasons for they attracting the brightest graduates is exposure to the technology at the frontier in the Indian operations. All this put together, there is a significant contribution of TNCs for human capital formation both in scale in terms increasing number of skilled graduates and also upgradation of skills.

The negative side of this is that it inhibits the movement of small local firms into higher end operations. Most of the high skill graduates prefer to work for the well-known TNCs for their brand name and technology and large Indian firms and also migrate to the US. Therefore the smaller and also several large Indian firms have to do with low-end skilled manpower. Our field interview of Indian firms show that these firms hire from local engineering colleges, which are not at the higher level, impart training to them for three to four months. Some of the local firms make employees to sign a three-year job contract. With these skills the Indian firms can undertake software development only at the lower end. Secondly, the smaller firms become training grounds for the TNCs and firms in the US because once the workers gain enough experience they leave for working for TNCs and to the US.

In the case of proposition 3, software firms are concentrated in Bangalore, Chennai, and Hyderabad of the Southern India, Pune of Western India, and Gurgaon of the Northern India. Several TNCs and large Indian

\footnotetext{
${ }^{20}$ In the beginning of 2001, US based majors like Cisco, IBM, GE and Ford announced investment plans worth over a billion US dollars for the following two years which is expected to create 10,000 IT professional jobs. General Electric is investing \$100 million in Bangalore to build its largest R $\$ \mathrm{D}$ lab in the world, employing 2,600 scientists including more than 300 with Ph.D degrees. The technological evolution of the industry is supported by the fact that more than half of the software development centers in the world with Carnegie Mellon University’s CMM Level-5 rating are located in India (Kapur and Ramamurti, 2001).
} 
firms have multiple development centers in all these cities. As we gathered in our field interviews, since fixed costs of physical capital in this industry is very low, duplicating plants does not cause loss of economies of scale. Since the critical input is human capital, the multiple centers are set up to tap into locally available skilled workers. However, the development at the higher end of R\&D work is concentrated in Bangalore owing to the strong agglomeration economies of the cluster. Of all these, Bangalore has become the most dynamic high-tech cluster for the reasons discussed in the Section 3. Most of the TNCs and leading Indian firms development centers are concentrated in Bangalore. In Bangalore alone there are about 140 TNC development centers. There are about 750 large and small domestic IT firms. About 40 per cent of India's total exports of \$ 8.3 billion in 2001 have come from Bangalore. There are about 60,000 IT professionals employed in Bangalore.

There is mobility of skilled workers among TNCs and local firms. As gathered from our field interviews, entrepreneurs who worked for TNCs and became successful innovators started a few new firms. A few TNCs also functioned as ventured capitalists in supporting the start-ups. The export orientation of the cluster also makes the skilled workers to move in and out to the developed economies, which causes free flow of ideas and spillovers. In Bangalore, there are strong joint ventures and partnership agreements among TNCs and TNCs and local firms. This facilitates effective realization of technology spillovers.

In the case of the proposition (4) regarding backward and forward linkages of TNCs, we bring out some broad patterns with regard to the nature of the operations of TNCs in order to shed some light for their implications on human capital accumulation. The backward linkages are in terms of linkages with the local universities and research institutions and local firms and forward linkages is with respect the linkage with the parent company and international markets. There are broadly three types of operations of TNCs: (1) sales and service, (2) software development (programming and coding) and (3) research and development. In the case of the first one, leading IT companies such as Microsoft, Oracle and IBM, have a strong incentive in promoting their technology and platforms, especially with lock-in characteristic, with local firms and consumers and IT graduates of universities. They aggressively collaborate with local firms and provide free training for their employees on their platforms. Furthermore, several of the companies invest directly in the universities and engineering colleges and private training institutions such NIIT and 
APTECH for developing curriculum and training teachers on the technologies to promote their platforms. As mentioned before, in collaboration with the government and large Indian firms, TNCs started IIITs in major cities in India. However several of TNCs such TI, INTEL, and Oracle also invest in the universities and research institutions for the general-purpose skills. For example, recently, INTEL has announced to train 100,000 teachers in Internet and IT tools in India and Cisco, as mentioned before, has announced to set up 34 regional networking academics in the country. TNCs such as INTEL and CISCO also function as venture capital funding in providing capital and technology and training to entrepreneurs in India. This strategy is crucial for the leading international firms not because of local market size but because the Indian industry has become a major software development center for the global market. This part of the linkage is the direct contribution to the human capital generation in India. The other aspect is the spillover effect through the linkages. In the case of high level research and development operations, a few TNCs got into joint ventures with local firms (such as Nortell and H\&P). In such cases, TNCs provided technology and training to local firm's skilled personnel at the frontier of the technology. However, at the higher end of R\&D operations, TNCs are reluctant to outsource projects to local firms in which case the spillover effects are low. Except in a few cases such as Adobe and TI's Digital Signal Processing R\&D, most TNCs R\&D operations are in support of parents' R\&D. In this case, there is generally a frequent movement of skilled personnel to the parent's center and the operations in India, which is an effective channel for reduction in idea gap and information externalities. In the case of lower end operations of software programming, coding and data work, as we gather from our fieldwork, there is higher incidence of outsourcing to Indian firms. However, in the case of these operations, the learning economies are low owing to the low-end technology.

\subsection{The Econometric Analysis}

The objective of the econometric analysis is to test for whether the increasing presence of TNCs in India's software industry contributes positively to productivity of Indian software firms. As mentioned in Section 2, the main sources of productivity growth in the IT industry are human capital accumulation and technological change. A positive association between firm level productivity and degree of TNC presence 
in the industry would imply that TNCs contribute to human capital accumulation and technological change through the mechanisms discussed in the previous sections.

The econometric exercises are based on firm level panel data for 20 large Indian firms covering the period of 1990 to 1999. The data were collected from the publications of the Center for Monitoring Indian Economy (CMIE) which publishes comprehensive firm level data for the Indian public limited companies annually. The panel data analysis captures the dynamics of change because of inclusion of both crosssectional and time-series dimensions. It makes use of information on both inter-temporal dynamics and individuality of entities being investigated which controls for the effects of missing or unobserved variables (Cheng, 1986). Fixed effects are controlled by firm specific dummy variables, which also reduce the bias caused by omitted variables.

\section{2.a. The variables}

$T F P=$ firm level relative productivity (see the Appendix 2 for the measurement issues)

$T N C=$ degree of TNC presence in the industry (total sales of TNCs/ total industry sales)

$R D S=$ research and development expenditure/sales

$E X I M=$ degree of international orientation of firms $($ exports + imports $) / s a l e s$

$R T=$ royalties and technical fees paid by firms/sales. This variable captures the extent of technological joint ventures of local firms with TNCs.

D1...Dn. firm specific dummy variables to capture the fixed effects of the panel data

\section{2.b. The Results}

$$
\begin{aligned}
& T F P=0.5+0.3(T N C)+1.4(R D S)+0.5(E X I M)+0.32(R T)-0.3(D 1)-0.17(\mathrm{D} 2)-0.8(D 3)^{21} \\
& (19)^{*}(2.2)^{*} \quad(3.4)^{*} \quad(2.9)^{*} \quad(5.3)^{*} \quad(1.5) \quad(4.9)^{*} \quad(2.7)^{*}
\end{aligned}
$$

\footnotetext{
${ }^{21}$ In order to save on the space, we report the estimated coefficients of the firm specific dummies only for the three cases.
} 
Adjusted $R 2=0.35 \quad F=8 \quad N=129$

The above results show high degree of statistical significance with the appropriate signs of the estimated coefficients providing support to some of the main propositions of the paper. The variables TNC and RT capture the effect of TNCs on the productivity of Indian firms in a direct manner. The estimated coefficient of TNC variable is positive and statistically significant which implies increasing presence of TNCs in the Indian software industry contributes positively to the productivity of firms. This mechanism could be in several ways- through spillovers, backward linkages with local firms and educational institutions as illustrated in the previous section. The variable RT (royalties and technical fees to sales) captures one of the aspects of backward linkages of TNCs with local firms. Firms with technological collaborations with TNCs pay royalties and technical fees. The positive sign and statistical significance of the estimated coefficient of this variable implies that those firms with higher degree of technological collaborations realize higher level of productivity. The technological linkages are a source of spillovers and technology transfer to local firms.

As discussed under the proposition 5 in Section 2, local firms have to make their own effective technological efforts in terms of investing in R\&D and training of manpower for effective realization of the benefits of possible spillovers from the operations of TNCs in a developing economy. The positive sign and statistical significance of the estimated coefficient of the R\&D variable provides supports to this proposition. As postulated in the new growth theory, free international trade for a developing economy with developed economies is a significant source of productivity growth through possible informational and technological externalities. The positive sign and statistical significance of the estimated coefficient of the variable EXIM provides support to this argument.

\section{The Conclusion}

The striking feature of India's software industry is that it is a rapidly growing and internationally competitive high-tech industry from a developing economy. It currently employs about 300000 people and accounts for 2 percent of India's GDP and is expected to account for 7.7 percent by 2008 (NasscomMckinsey Study 1999). It accounts for 14 per cent of India's total exports currently there are several factors 
that have contributed for its birth and growth. This paper has focused on the issue of role of TNCs in its evolution.

The theoretical framework of the paper focuses at the effect of TNC operations on human capital accumulation and productivity drawing mostly from the new growth theory. The empirical analysis is based on both the qualitative information collected from extensive field interviews of managers of TNCs subsidiaries and local firms and also econometric analysis of firm level panel data. The analysis shows that TNCs played a very important and critical role in the growth and competitiveness of the industry.

The new growth theory shows that openness to trade and investment is an important source of economic growth to developing economies. This is because most of new technologies and ideas are generated in developed economies with large investments in R\&D and openness functions as channel for the free flow of ideas and technology and the associated externalities. However, it is not an automatic process. For openness to benefit developing economies it requires two conditions: (1) a developing economy needs to have to a certain level of initial human capital and industrial endowments and (2) local firms and governments have to make their technological efforts to increase absorbive capacity of new technologies and ideas.

The initial human capital stock of large pool engineers generated by the past policies in India led to the entry of TNCs to utilize the low-cost skilled manpower. The entry of TNCs has led to a dynamic process of further accumulation of human capital and consequent economic growth. The process can be broadly seen in terms of market structure dynamics and spillovers or externalities. In terms of market structure dynamics, most TNCs entered the Indian industry for utilizing low-cost skilled labor for their global operations. Export orientation of the firms relaxed domestic market size constraint and allowed entry of large number of TNCs since the mid-80s. Several of them expanded their operations significantly over the years. This led to rapid increase in demand for skilled workers and consequently the wage rate, which have provided incentives for the acquisition of both general and specialized skills. This led to further supply side 
response of both the private schools and the government educational institutions expanding educational infrastructure.

For technological externalities to be significant TNCs have to operate at high-end of technology and build backward linkages with the local economy. The spillovers would be more dominant if the industry is organized into a dynamic cluster such as the one Bangalore in India. TNCs operations provide demonstration effect on local firms, which helps them to imitate practices of TNCs. As illustrated in the Section 4, several TNCs operate at the high-end of R\&D mostly in the cluster of Bangalore in India. Quite a few of them developed strong linkages with local firms and educational institutions. The econometric results also provide significant proof of contribution of TNCs to local firm's productivity.

There are several other indirect benefits of TNCs operations in this industry. For example, the growth of the industry in terms of being a major wealth and employment generator has led to evolution of market institutions in the positive direction. For example, the Indian government amended the copyright act in 1994 in order to enforce copyright protection. The corporate governance practices of the Indian IT firms have become ideal norm for the rest of the industries. Secondly, this industry has shown the benefits of openness to trade and investment which in turn has built a political consensus to the reforms of opening up of the Indian economy. Furthermore, the government of India both at the center and state levels have taken an active role in promoting this industry and also targeting other high-tech industries such as biotechnology for the supply side supports. For example, the government of India has announced recently setting up of Rs 5,1300 million IT research project in collaboration with MIT, Cambridge for promotion of innovation. The lab will have a chain of regional laboratories, linked together to facilitate invention, refinement and deployment of innovation that benefits the masses.

There are a few policy implications for other developing economies from the case of India's software industry. To recapitulate, for openness to trade and investment to cause economic growth in developing economies, they need to have a certain level of initial endowment of human capital and technological institutions. This requires government investment in higher education and research and development. 
Secondly, for local firms and skilled manpower to absorb the externalities emanating from the operations of TNCs and free international trade, local firms and governments have to make their technological efforts. These efforts are in terms of investing in R\&D and education and training in tune with the rapidly changing technology in the world market. On the demand side, there should not be any intervention of the government in distorting the world market price signals. The intervention on the demand side could be in terms of reducing informational imperfections regarding the local market conditions to TNCs and world market conditions to local firms.

\section{References}

Aitken, B., Harrison, A., 1999, 'Do Domestic Firms Benefit from Foreign Direct Investment? Evidence from Venezuela’ American Economic Review, Vol 89 (3), pp.605-618.

Aitken, B., Harrison, A., 1993, 'Does proximity to foreign firms induce technology?', Working paper (World Bank).

Archibugi, D and S. Iammarino, 1999, 'The Policy Implications of the Globalization of Innovation', Research Policy, 28, 317-336.

Arora, A and J. Asundi, 1999, Quality Certification and the Economics of Contract Software Development: A Study of the Indian Software Industry, Working Paper, NBER.

Balasubramanyam, V.N. and A. Balasubramnayam, 1999, 'The Software Cluster in Bangalore,' in J.H. Dunning (eds), Regions, Globalization, and the Knowledge-Based Economy, New York, Oxford University Press.

Baptista, R, 2000, 'Do Innovations Diffuse Faster Within Geographical Clusters ?' International Journal of Industrial Organization, 18, 515-535.

Bartlet, C.A., Ghoshal, S., 1995, Transnational Management, Irwinn, London.

Basant, R., P. Chandra and L.K. Mytelka, 1998, 'Strategic Partnering in Telecom Software: Northern Telecom's Technology Network in India', Working paper no 98-07-01, Indian Institute of Management, Ahmedabad.

Battese, G., and Coelli, T, 1992, `Frontier Production Functions, Technical Efficiency and Panel Data: With Application to Paddy Farmers in India,' Journal of Productivity Analysis, 3:1/2, 153-169.

Becker, G, 1964, Human Capital, Columbia University Press. New York.

Bell, M and M.Albu, 1999, 'Knowledge Systems and Technological Dynamism in Industrial Clusters in Developing Countries,' World Development, vol.27, no.9, 1715-1734.

Blomstrom, M and F.Sjoholm, 1999, 'Technology Transfer and Spillovers: Does Local Participation with Multinationals Matter' European Economic Review, 43, 91-923. 
Branstetter, L.G., 2000, Is Foreign Direct Investment a Channel of Knowledge Spillovers?

Evidence from Japan's FDI in the United States' Dept of Economics, University of California, Davis.

Branstetter, L.G., 2001, 'Are Knowledge spillers international or intranational in scope ? Microeconometric evidence from the U.S. and Japan' Journal of International Economics, 53, 5379.

Cantwell, J, 1989, Technological Innovation and Multinational Corporations, Cambridge, MA: Blackwell.

Caves, R.E, 1974, Multinational firms, competition and productivity in host country markets, Eonomica, 41: 176-93.

Caves, R.E., 1996, Multinational enterprise and economic analysis, Cambridge University Press, Cambridge.

Coe, D.T and E.Helpman, 1995, 'International R\$D Spillovers' European Economic Review, 39, 859-887.

Cohen, W.M., Levinthal, D.A., 1989, Innovation and Learning: the Faces of R\&D. Economic Journal 99, 569-596.

Cornwell, C., Schmidt, P., Sickles,R., 1990, Production frontiers with cross-sectional and Timeseries variation in efficiency levels, Journal of Econometrics 46, 185-200.

De Mello.Jr., L.R, 1997., 'Foreign direct investment in developing countries and growth: A selective survey', Journal of Development Studies, 34, 1-34.

Dheer, S and B. Viard, 1995, 'Tata Consultancy Services: Globalization of Software Services', Stanford Business School Case Study.

Dossani, Rafiq, 1999, `Assessing Venture Capital in India,' Asia/Pacific Research Center, Stanford University.

Dunning, J.H, 1993, Multinational Enterprises and the Global Economy, New York:AddisonWesley Publishing Company.

Dunning, J. H, 1981., International Production and the Multinational Enterprise, George Allen and Unwin, London.

Farrell, M, 1957., The measurement of production efficiency, Journal of Royal Statistical Society, 120(3), 253-281.

Fosfuri, A., M.Motta and T.Ronde, 2001, 'Foreign Direct Investment and Spillovers through Worker's Mobility' Journal of International Economics, 53, 205-222.

Geroski, P. A., 2000, ‘Models of Technology Diffusion,' Research Policy 29, 603-625. 
Ghemawat, P., Patibandla, M., 1999, 'India's exports since the reforms: Three analytic industry studies', in Jeffrey Sachs.,Varshney, A., Bajpai,N (Eds), India in the Era of Economic Reform, Oxford University Press, Delhi.

Ghemawat, P, M. Patibandla, and B.Coughlin, 1999, India's Software Industry at the Millenium, Harvard Business School Case Study, N9-700-036.

Grossman, G and E. Helpman, 1991, Innovation and Growth in the Global Economy, The MIT Press, Cambridge.

Hanna, N, 1994, 'Exploiting Information Technology for Development: A Case Study of India,' World Bank, Discussion Paper No.446.

Heeks, R., 1998, 'The Ueven Profile of Indian Software Exports', Working paper no. 3, Department of Informatics, University of Manchester.

Heeks, R., 1996, India's Software Industry, Sage Publications; New Delhi.

Heitzman, J, 1999, 'Corporate Strategy and Planning in the Science City: Bangalore as 'Silicon Valley', Economic and Political Weekly, January, 30, PE-2-PE-11.

Hejazi, W and A. E. Safarian, 1999, Trade, Foreign Direct Investment, and R\&D Spillovers, Journal of International Business Studies, 30 (3), 491-511.

Hirschman, A.O., 1958, The Strategy of Economic Development, New Haven: Yale University Press.

Kapur, D and R. Ramamurti, 2001, 'India's Emerging Competitive Advantage in Services', Academy of Management Executive, vol.15, no.2, 20-33.

Kobrin, J. S., 1999, 'Development After Industrialization: Poor Countries in an Electronically Integrated Global Economy', in Nielhood and S. Young (eds), The Globalization of Multinational Enterprise Activity and Economic Development, London: Macmillan.

Kokko, A, 1996, 'Productivity Spillovers from Competition between Local Firms and Foreign Affliates, Journal of International Development, 8(4): 517-530.

Kokko, A., 1994., 'Technology, market characterstics, and spillovers', Journal of Development Economics, 43, 279-293.

Krugman, P.R., 1991, Georgraphy and Trade. Leuven, Belgium: Leuven University Press and Cambridge, M: MIT Press.

Liu, X., Siler, P., Wang, C and Wei, Y, 2000, Productivity spillovers from foreign direct investment: Evidence from UK Industry Level Panel Data, Journal of International Business Studies, 31 (3) 407-425.

Lucas, R.E, 1993, ‘Making a Miracle,' Econometrica, 61: 251-72. 
Lucas, R. E, 1988, 'On the Mechanics of Economic Development,' Journal of Monetary Economics, July, 22:1, 3-42.

MacKie-Mason, J.K and H.R. Varian, 1994, 'Some Economics of the Internet, Department of Economics, University of Michigan.

Metiu, A and B. Kogut, 2001, 'Distributed Knowledge and the Global Organization of Software Development, Wharton School, University of Pennsylvania.

Nasscom Report, 2000, http://www.nasscom.org.

North, D., 1990, Institutions, Institutional Change and Economic Performance, Cambridge: Cambridge

University Press.

Patibandla. M, 2001., 'Policy reforms and evolution of market structure in an emerging economy', Forthcoming in the Journal of Development Studies.

Patibandla, M., D. Kapur and B. Petersen, 2000, 'Import Substitution with Free Trade: the Case of India's Software Industry,' Economic and Political Weekly, April 8, 1263-1270.

Porter, M., 1990, The Competitive Advantage of Nations, New York: Free Press.

Raut, L.K, 1995. 'R\&D Spillovers and Productivity Growth: Evidence from Indian Private Firms,' Journal of Development Economics, 48: 1-23.

Romer, P. M, 1990 `Endogenous Technological Change,' Journal of Political Economy, 98,S71-102.

Romer, P.M, 1986, 'Increasing Returns and Long-Run Growth,' Journal of Political Economy, 94:5, 1002-37.

Rotenberg, J.J and G. Saloner, 2000, 'Competition and Human Capital Accumulation: A Theory of Interregional Specialization and Trade' Regional Science and Urban Economics, 30, 373-404.

Sanyal, A., and Patibandla, M., 1998., 'From closed to contestable markets in Indian durable consumer goods industry', Working paper BPP-70, Institute of Management, Innovation and Organization, the Haas School of Business, University of California at Berkeley.

Saxenian, Annalee, 1999, Silicon Valley: New Immigrant Entrepreneurs, San Fransisco, Public Policy Institute of California.

Saxenian, Annalee, 1996, Regional Advantage: Culture and Competition in Silicon Valley and Route 128, Cambridge: Harvard University Press.

Shapiro, C, and H. Varian, 1999, Information Rules, (Harvard Business School Press: Cambridge).

Subramanian, C. R., 1992, India and the Computer, Oxford University Press: New Delhi.

Varian, H. R., 1998, 'Market for Information Goods,' University of California, Berkeley.

UNCTAD, 1999, World Investment Report, Geneva.

Williamson, O.E, 1985, The Economic Institutions of Capitalism, Free Press, New York.

World Bank, 1990, World Development Report, Oxford University Press. 


\section{Appendix 1:India's Software Industry: The Background}

Software industry can be classified into three broad groups: 1) Packaged software, 2) Professional services consisting of software consulting, custom programming, systems integration, data processing, and facilities management, and 3) Operations and Back-office services covering maintenance and back office work such as document conversion, data entry, claims processing and medical transcription. The package segment requires, especially in the generic segments, huge investments in Research and Development and marketing. This segment of the world market is dominated by large American firms such as Microsoft, IBM, Oracle etc. In broader terms, the US and other developed countries specialized in higher end products and services while developing countries such as India with low skilled labor costs focused on lower-end services such as support services, coding, maintenance, data feeding, systems software and utilities, and niche market packages (Ghemawat, Patibandla, Coughlin, 1999). Software development can be characterized in terms of the waterfall model, which divides the development into (1) requirement analysis, (2) design (3) coding (4) testing (5) acceptance testing/implementation and (6) maintenance. The first two parts require high levels of skills and research and development. The later parts require lower levels of skills but are manpower intensive. The later part of the development is the one where most Indian firms and also major part of TNCs operations in India fall.

We briefly trace out the birth and growth of India's software industry in the following. Since its independence from the British in 1947 till 1991, India followed a development strategy of import substitution and planning. As a part of the import substitution strategy, the Indian government invested huge capital in setting up the public sector units in high technology areas such as the electronic industry and also it invested large amounts in higher technical education. During the second five-year plan (195762), the Indian government launched a massive program of advanced technology training programs and set up the elite Indian Institutes of Technology and the regional engineering colleges. These institutes started to produce large pool of highly skilled technical manpower, which later on became the major source for the growth of the software industry. The graduates of these institutes have been providing skills for the local industry and also in building up the network (the ethnic ties) with the US information technology industry. 
The import substitution policy, although it generated a large industrial base, generated public and private sector monopolies and caused all round inefficiencies. Consequently, the skilled graduates generated by the institutes could be not absorbed and utilized efficiently by the local industries.2. This promoted a largescale brain drain to the US, which later became a strong source of the ethnic network to the Indian industry especially between the Silicon Valley and the Indian software industry (Saxenian, 1999). Secondly, the general training in mathematics and engineering became a source of skilled manpower to the local industry.

Large-scale investment by the US government in the defense industry research in 1950s led to the birth of the US information technology industry. The birth of the Internet technology in 1980s also owed to the investments by the US defense department (Mackie-Mason and Varian, 1994). Similar to the US industry, the birth of India's information technology industry owed to the public sector investments. The first computer was introduced in India in 1956 for use at the Indian Statistical Institute. Around mid-1960s, the government of India started a policy towards localizing production of computers. Towards this, the government set up the public sector firms, The Bharat Heavy Electronics in Bangalore. In 1968, the private sector firm, the Tata Consultancy Services (TCS) was created. In the initial years, it did software development for its own conglomerate group of firms and for the public sector units. In the early seventies, the department of electronics was created by the government to promote the IT industry. Around this time, a few private software vendor firms entered the industry to serve the public sector firms for custom software development. The government also initiated software-related training in the Indian Institute of Technology and universities. For promoting software exports, in 1972 hardware imports were permitted for use in software exports with the condition that the importer had a commitment to earn the foreign exchange for imports through software exports. Fortunately, the industry was not subjected to industrial licensing policies. The exit of IBM in 1977 from India also gave boost to the local private sector firms such as the TCS. As a result of the exit of IBM, the government of India set up the Computer Maintenance Corporation. The closed-door and the industrial licensing policies restricted the growth and competitiveness of the computer hardware industry. But a by-product of the import substitution policies was the emergence of the software industry (Patibandla, Kapur and Petersen, 1999). As the software imports were prohibited

\footnotetext{
${ }^{22}$ Hirshman (1958:5) argued that the important factor in economic development was enlisting for
} 
during this period, private software firms initially operated as data entry operators in the domestic market by developing their own software (at very low level of sophistication) and processing data from clients into reports by purchasing one or two computers. Software exports, in the form of onsite projects, started to take place in the early eighties. Around this time, the government of India started to promote software exports by providing skills, infrastructure, and legal regulation and marketing assistance. By 1984, the policy was made liberal in allowing 100 percent foreign subsidiaries, imports of hardware and software (Heeks, 1996). In 1991, the government set up software technology parks (STP) in major cities such as Bangalore. The STPs provided the industry with telecommunications infrastructure, power and roads. The relatively liberal policy towards TNCs in this industry facilitated the setting up of Texas Instruments Subsidiary in Bangalore in 1985 with the most advanced communication technology of direct satellite link with its home operations in Dallas. Later 1989, Hewlett-Packard set up a 100 percent-owned subsidiary in Bangalore for exports.

In 1991, the Indian government undertook the general reforms on the internal and external front for dismantling the import substitution regime. As part of this, the Indian rupee was devalued substantially which gave further incentive for software exports. Imports of telecommunication equipment, hardware and software products were liberalized and the STPs were provided with trade-openness. Consequently, software industry could reduce its dependence on the domestic hardware and telecommunication industry. Large firms were able to build their own satellite connections with the clients overseas. As software is digital, satellite links facilitates exports of services with marginal communication and zero transportation costs. This prompted large Indian firms to reduce onsite projects and develop offshore projects through the satellite links. Consequently, since the early 90 s software exports grew very rapidly at an annual average growth rate of 50 percent (see Table 1). As the industry has started to become a major wealth generator, the government of India amended the copyright act in 1995 to control software piracy. This gave an impetus for the growth of the domestic market and entry of TNCs for serving the local market in the later part of the 1990s. The above discussion shows the critical role of the government policy especially on the supply side in terms of investment in higher education, and infrastructure in the birth and the growth of the industry. On the demand side, the liberal trade-open policies on the external front especially directed at this

development purposes resources and abilities that are hidden scattered or badly utilized. 
industry from the relatively earlier stages contributed to its export competitiveness. Secondly, since the early-80s, multinational investment into the industry is highly encouraged without any restrictions on the foreign equity control. This led to entry of a large number of TNCs into the industry. By 2001, all most all the leading American and European IT firms have set up development centers in India.

\section{Appendix 2: Measurement of Firm Level Productivity}

Productivity is defined in terms of magnitude of output realized for any given level of inputs employed.

The production function frontier approach of Farrel (1957) is quite effective in measuring micro firm level relative productivity within an industry. The production relation can be expressed as:

$Y=(X: a)+u$, where $Y$ is a vector of input observations and $X$ is a matrix of input observations, $a$ represents the parameters and $u$ represents one-sided error. Frontier estimations take $\mathrm{u}$ to have negative expectation, indicating the presence of (technical) efficiency. In the present case, $u$ is taken to consist of two parts- a normally distributed error term that represents statistical noise and a truncated error term that represents technical inefficiency. Stochastic frontier functions isolate differences in efficiency and random differences among firms by dividing the error term into a deterministic component and a random one. Panel data estimations help in avoiding some strong assumptions. Under the fixed effects approach, there is no need to assume a probability distribution for the inefficiency index and it has the advantage of dispersing with the assumption that firm level inefficiencies are uncorrelated with input levels. The random approach, on the other hand, requires to assume that firm level inefficiencies and input levels are independent but unlike the fixed effects approach, it can accommodate time-invariate variables such as industry or firm dummies. The inefficiency component can be modeled as a function of a number of firm specific factors. Battese and Coelli, 1992 show the simultaneous estimation of both the production function and the inefficiency term. We have taken a two input production with value-added as a function of rental value of capital and salaries and wages as labor input. The values normalized by the appropriate price indices of producer and consumer prices. We have estimated a two input Cobb-Douglas production. The output is value-added $(Y)$, capital input is rental value of capital $(K)$ and labor input is salaries and wages paid $(L)$. ' $t$ ' represents the year. The estimated production function is as follows: 
$\log Y=0.23+0.1(t)+0.03(t) 2+0.49 \log L+0.16 \log K$

$$
(5.5)^{*}(0.1) \quad(4.6)^{*} \quad(12.3)^{*} \quad(6.0)^{*}
$$

Adjusted R2 $=0.94 \quad \mathrm{~F}=155 \mathrm{~N}=129$

The above results show a lot higher value of the estimated coefficient of labor input than that of capital input which is expected for the human capital intensive software industry.

Table 1. India's Software Exports (Rs. Billion/\$ Million)

\begin{tabular}{|l|l|l|l|}
\hline Year & Exports & $\begin{array}{l}\text { Domestic } \\
\text { Sales }\end{array}$ & $\begin{array}{l}\text { Exports/ } \\
\text { Total Sales } \\
(\%)\end{array}$ \\
\hline $1987-88$ & $\begin{array}{l}\text { Rs. } 0.70 \\
\$ 52\end{array}$ & Rs. 1.00 & 41 \\
\hline $1990-91$ & $\begin{array}{l}\text { Rs. } 2.50 \\
\$ 128\end{array}$ & Rs. 2.25 & 52 \\
\hline $1991-92$ & $\begin{array}{l}\text { Rs. } 4.30 \\
\$ 164\end{array}$ & Rs. 3.20 & 57 \\
\hline $1992-93$ & $\begin{array}{l}\text { Rs. } 6.70 \\
\$ 225\end{array}$ & Rs. 4.90 & 57 \\
\hline $1993-94$ & $\begin{array}{l}\text { Rs. } 10.20 \\
\$ 330\end{array}$ & Rs. 6.95 & 59 \\
\hline $1994-95$ & $\begin{array}{l}\text { Rs. } 15.30 \\
\$ 485\end{array}$ & Rs. 10.70 & 59 \\
\hline $1995-96$ & $\begin{array}{l}\text { Rs. } 25.20 \\
\$ 735\end{array}$ & Rs. 16.70 & 60 \\
\hline $1996-97$ & $\begin{array}{l}\text { Rs. } 39.00 \\
\$ 1110\end{array}$ & Rs. 25.00 & 61 \\
\hline $1997-98$ & Rs. 65.3 & Rs. 35.8 & 64 \\
\hline
\end{tabular}




\begin{tabular}{|l|l|l|l|}
\hline & $\$ 1790$ & & \\
\hline $1998-99$ & $\begin{array}{l}\text { Rs. } 109 \\
\$ 2650\end{array}$ & Rs. 49.5 & 68 \\
\hline $1999-00$ & $\begin{array}{l}\text { Rs. } 171.5 \\
\$ 4000\end{array}$ & $\begin{array}{l}\text { Rs. } 72 \\
\$ 1700\end{array}$ & 70 \\
\hline $2000-1$ & $\begin{array}{l}\text { Rs. } 283 \\
\$ 6320\end{array}$ & $\begin{array}{l}\text { Rs 94 } \\
\$ 2060\end{array}$ & 70 \\
\hline
\end{tabular}

* Figures not available.

Note: The figures for the domestic software activity do not include in house development of software by end users which is presumed to be a considerable amount.

Sources: www.nasscom.org; Heeks [1996].

Table 2. India's Software Exports by Activity (Percentage of total software exports)

\begin{tabular}{|c|c|c|c|c|c|}
\hline & $1990-91$ & 1995-96 & $1997-98$ & & 1998-99** \\
\hline $\begin{array}{l}\text { Professional } \\
\text { Services }\end{array}$ & 90 & 48 & 48.9 & \begin{tabular}{|l} 
Professional \\
Services
\end{tabular} & 44.15 \\
\hline a) Off-shore & 18 & 19 & 25 & & $34 \%$ \\
\hline b) On-site & 72 & 29 & 23 & & $58 \%$ \\
\hline $\begin{array}{l}\text { Consultancy and } \\
\text { Training }\end{array}$ & * & 26 & 30 & Training & 1.72 \\
\hline Data Processing & 0 & 10 & & Projects & 36.50 \\
\hline Other Services & 5 & 4 & 3 & $\begin{array}{l}\text { Support and } \\
\text { Maintenance }\end{array}$ & 4.25 \\
\hline \multirow[t]{2}{*}{$\begin{array}{l}\text { Products and } \\
\text { Packages }\end{array}$} & 5 & 12 & 8.8 & $\begin{array}{l}\text { Products and } \\
\text { Packages }\end{array}$ & 7.90 \\
\hline & & & & \begin{tabular}{|l|} 
IT Enabled \\
Services \\
\end{tabular} & 5.48 \\
\hline Total & $\begin{array}{r}100 \\
\text { (Rs 2.5 billion) } \\
\end{array}$ & $\begin{array}{r}100 \\
\text { (Rs } 25.2 \text { billion) } \\
\end{array}$ & (Rs 65.3 billion) & & $\begin{array}{r}100 \\
\text { (Rs 109.4 billion) }\end{array}$ \\
\hline
\end{tabular}

* Included in On-site Professional Services in 1990-91.

** The classifications have changed in 1998-99.

Source: Nasscom.

Table 3. IT Industry in India

1994-95

1995-96

1996-97

1997-98

1998-99 1999-2000

\begin{tabular}{|l|l|l|l|l|l|l|l|l|l|l|l|l|}
\hline & Rs. $\mathrm{m}$ & $\begin{array}{l}\text { US } \\
\mathrm{m}\end{array}$ & Rs. $\mathrm{m}$ & US\$m & Rs. $\mathrm{m}$ & US\$m & Rs. $\mathrm{m}$ & US\$m & Rs. $\mathrm{m}$ & US\$m & Rs. $\mathrm{m}$ & US\$m \\
\hline Software & & & & & & & & & & & & \\
\hline Domestic & 10,700 & 350 & 16,700 & 490 & 24,100 & 670 & 35,100 & 950 & 49,500 & 1,250 & 72,000 & 1,700 \\
\hline Exports & 15,350 & 485 & 25,200 & 734 & 39,000 & 1,083 & 65,300 & 1,750 & 109,400 & 2,650 & 171,500 & 4000 \\
\hline Total & 26,050 & 835 & 41,900 & 1,224 & 63,100 & 1,753 & 100,400 & 2,700 & 158,900 & 3,900 & 243,500 & 5,700 \\
\hline Hardware & & & & & & & & & & & & \\
\hline Domestic & 18,300 & 590 & 35,600 & 1,037 & 37,800 & 1,050 & 44,970 & 1,205 & 42,350 & 1,026 & 62,000 & 1,450 \\
\hline
\end{tabular}




\begin{tabular}{|l|l|l|l|l|l|l|l|l|l|l|l|l|}
\hline Exports & 5,500 & 177 & 1,200 & 35 & 10,300 & 286 & 7,430 & 201 & 155 & 4 & 3,700 & 86 \\
\hline Total & 23,800 & 767 & 36,800 & 1,072 & 48,100 & 1,336 & 52,400 & 1,406 & 42,505 & 1,030 & 65,700 & 1,536 \\
\hline Peripherals & & & & & & & & & & & & \\
\hline Domestic & 4,590 & 148 & 6,720 & 196 & 6,530 & 181 & 8,330 & 229 & 13,600 & 329 & 18,700 & 435 \\
\hline Exports & 180 & 6 & 210 & 6 & 520 & 14 & 680 & 19 & 730 & 18 & 1,150 & 27 \\
\hline Total & 4,770 & 154 & 6,930 & 202 & 7,050 & 195 & 9,010 & 248 & 14,330 & 347 & 19,850 & 462 \\
\hline Training & 3,310 & 107 & 4,970 & 145 & 6,600 & 183 & 9,420 & 263 & 12,500 & 302 & 17,200 & 400 \\
\hline Maintenance & 4,400 & 142 & 5,920 & 172 & 6,560 & 182 & 8,240 & 221 & 9,780 & 236 & 11,300 & 263 \\
\hline $\begin{array}{l}\text { Networking } \\
\text { \& Others }\end{array}$ & 1,120 & 36 & 2,400 & 710 & 5,590 & 156 & 7,150 & 193 & 9,800 & 237 & 13,250 & 310 \\
\hline Grand Total & 63,450 & 2041 & 98,920 & 2886 & 137,000 & 3805 & 186,620 & 5,031 & 247,815 & 6052 & 370,800 & 8,671 \\
\hline
\end{tabular}

